A. Klimczuk, Public Policy: Ethics, [in:] J. D. Wright (ed.), International Encyclopedia of the Social and Behavioral Sciences, 2nd edition, Elsevier, Oxford 2015, pp. 580-585.

http://doi.org/10.1016/b978-0-08-097086-8.75014-8

\title{
Public Policy: Ethics
}

Andrzej Klimczuk

Warsaw School of Economics, Warsaw, Poland

\begin{abstract}
There are many ethical dimensions of public policy. Public policy as actions to solve the collective problems includes directly or indirectly making ethical judgments. The public policy takes into account the reconciliation of conflicting interests of individuals, groups, and organizations, which is based on the values agreeing, which influences the objectives, principles, and styles of policy implementation. Ethical judgments about selecting more and less important, as well as more positive problem solutions, are present at all stages of the policy cycle.
\end{abstract}

\section{Introduction}

Public policy refers to structuring the government and society's actions, which are based on objectified knowledge and are taken to solve the key collective problems. These activities are carried out by using tools such as regulations, public programs, and strategies, stimulating cooperation, arguing, debating, studying, developing positive incentives to adopt expected attitudes, indicators of action effectiveness, evaluation, expertise, as well as by institutions including public offices and networks of commercial and non-governmental organizations (Howlett and Ramesh, 2003). Analysis of public policy includes both actions that are implemented, those that are not implemented, and those that represent alternative solutions to problems and may be taken.

Analysis and implementation of public policies is a cycle that usually includes the successive steps of agenda-setting, policy formulation, decision making, policy implementation, and policy evaluation. There are different styles of action at different stages of the policy cycle, which are subject to ethical choices and decisions of individuals, groups, and organizations (policy entities, actors). Public policy can also be understood as the functional and technical aspect of governance, whose essence is the control over public resources that need to be redistributed. The choice of mechanisms and logic of redistribution requires an ethical judgment. There are many types of public policies. Among the main are sectoral policies covering one thematic issue (e.g., health policy, education policy, environmental policy, innovation policy, economic policy); horizontal - crossing various topics (e.g., regional policy, 
A. Klimczuk, Public Policy: Ethics, [in:] J. D. Wright (ed.), International Encyclopedia of the Social and Behavioral Sciences, 2nd edition, Elsevier, Oxford 2015, pp. 580-585.

http://doi.org/10.1016/b978-0-08-097086-8.75014-8

family policy, social cohesion policy); and strategic, redistributive - related to financial transfers from one social group to another.

\section{Ethical Decision Making and Public Policy}

Ethics concerns the assessment of activities that we intend to take or do not intend to take. Includes consciously or subconsciously assessment in terms of good and evil, positive and negative actions, justice and injustice, as well as explaining how people define these differences. Choice of public policy is related directly to such ethical judgments during selecting what matters most and what matters not at all in an area affected by that policy. Ethics can be understood as a theory of morality or customs and habits. Morality as a social phenomenon is intended to regulate the relationship between individuals and social groups. Morality involves views and beliefs actually functioning in society, manifested in people's attitudes toward others, relations between them, and the capacity to cooperate. Morality is a form of social control, including evaluation, feedback, norms, sanctions, penalties, awards, role models, and ideals. Ethics is, therefore, a set of norms and ethical judgments which characterize a society or a certain ethical system (e.g., professional ethics, social ethics, honorary ethics). Ethics is divided into descriptive ethics - descriptive explanations of morality; normative ethics - evaluative analysis and assessment of morality; applied ethics - applying norms or standards to actual situations, issues; and meta-ethics - philosophical analysis of moral standards and assessments. Ethics includes the theory of values, which is setting ontological status of values, their hierarchy, and their possibility to achievement by a human. Based on research, ethics as a science formulates sets of rules enabling the implementation of the selected values. Values are all valuable, worthy of desire and choice of things, purposes, and meanings of human actions.

Applied ethics is mostly related to public policy as a moral reasoning and behavior of policymakers, policy analyst, and other stakeholders. Ethical judgments are expressed here by people's behavioral choices with social consequences, allocating resources, entitlements, and authorities. In the Western tradition, ethics was always related to politics (Capurro, 2005; Wolff, 2011). Basic relationships between public policy and morality can be described as four approaches (Dębowski and Jedynak, 1999). These are the primacy of politics over morality, the primacy of morality over politics, recognition of policy and morality as two autonomous areas, as well as the unity of politics and morality. The first approach assumes that political interest is more valuable than the existing moral principles, and if, whenever breaking the rules and norms is needed, this can be done - because 'the end justifies the means.' This position represents, 
A. Klimczuk, Public Policy: Ethics, [in:] J. D. Wright (ed.), International Encyclopedia of the Social and Behavioral Sciences, 2nd edition, Elsevier, Oxford 2015, pp. 580-585.

http://doi.org/10.1016/b978-0-08-097086-8.75014-8

among others, Machiavellian doctrine. The second approach - the primacy of morality over politics - assumes that loyalty to moral integrity is the most important and states that this position shall legitimate any political action. Among representatives of this position were Socrates and Mahatma Gandhi. The third approach is based on the assumption that politics and morality are two autonomous areas. This view assumes that political actions are taken by individuals and groups as far as their moral standards allow them. At the same time, separation of morality and politics is assumed here as equivalent to no engagement into politics of those persons who are not politicians. This view was formulated by Julien Benda. The fourth position is assuming unity of politics and morality. It is considered here that all policies are evaluated with regard to their moral significance. At the same time, the abstract moral standards should be subject to political assessments of effectiveness.

The three most important contemporary theories of ethical decision-making in public policy are consequentialism, deontological ethics, and virtue ethics (Sullivan and Segers, 2007; Boston et al., 2010). Consequentialism is related to evaluating human actions by good results, best outcome, the greatest possible increase of pleasure over pain, and the possible satisfaction of preferences in welfare economics. Critics show that this approach countenances sacrificing the interests of a few for the sake of the many, that there is no possibility to estimate all the possible or even probable consequences of a particular action or policy, and that the calculation of consequences is always subjective selection and interpretation of beneficiaries. Deontological ethics points out moral obligations or duties that people should fulfill apart from consideration of consequences. Rights and norms are priorities. People should be treated as ends rather than as means to purposes outside of themselves. The deontological approach promotes using published codes of ethics constructed by professional associations and public agencies. Virtue ethics refers to the sources of people's morality in their inner life and character. This approach is focused on certain ideals toward which people should strive to development of their humanity, such as honesty, courage, compassion, generosity, fidelity, integrity, fairness, and prudence.

In practice, none of these approaches independently provides a complete guide to action under all circumstances and on all stages of the policy cycle. Policymakers and analysts may employ different ethical principles and change them to improve policy outcomes. 
A. Klimczuk, Public Policy: Ethics, [in:] J. D. Wright (ed.), International Encyclopedia of the Social and Behavioral Sciences, 2nd edition, Elsevier, Oxford 2015, pp. 580-585.

http://doi.org/10.1016/b978-0-08-097086-8.75014-8

\section{Ethical Concepts in Public Policy}

A number of ethical concepts are used in public policy studies and practice. Particularly important are the concepts of interest, values, principles, and policy intervention styles.

\section{Interest}

The ability to create public policies adequate to solve the problems in the country can be understood as the ability to preserve its attributes of sovereignty. In other words, well-prepared mechanisms of public policies give a chance to adapt the country and its society to functioning in modern conditions, which is to compete for resources that will allow a decent quality of life. In this sense, public policy is a set of skills on management available public resources to achieve the highest possible added value for society (Zybała, 2012).

Ethical decision making is a highly complex process in contemporary public life. The difficulty lies here in the fact that public policy is usually practiced in a situation of limited resources. Therefore it requires from the government the ethical decisions on selecting activities that should engage these resources for best results (Bellinger, 2007). In addition, public policies are implemented in a situation where different social groups have different or conflicting interests. These groups have different resources, strength, and ability to pursue their interests. Implementation of policies in an efficient manner usually requires the establishment of a consensus among them or even a framework of consensus, which is, for example, public interest, social interest, or national interest. Excessive social conflict may, in fact, result that the economically weakest groups will hamper (by, e.g., protests, strikes, and social campaigns) important public actions and reforms. Therefore, governments typically run processes such as social dialogue and consultations in various forms.

Interests, as benefits of individuals, groups, or organizations usually includes the values and based on the rules of conduct (Supińska, 2008a). Interests primarily are features that enable and increase the chance of their satisfaction, they tend to give free access to the means of satisfying them, and they cause an actually high level of satisfaction. Diagnosis of interests requires a comparison of benefits and losses that may bring a concerted action in a specific situation. Thus, the interests are actions based on reflexivity, in contrast to actions based on impulses, emotions, or feelings. Conflicts of interest arise from the adoption by different individuals, groups, and organizations of different values, principles, needs, and goals, that although may be beneficial for some, can also be bad and harmful to others (Shue, 2006). For example, the decision to build the highway can improve the transport of goods, but also degrade the quality of life of 
A. Klimczuk, Public Policy: Ethics, [in:] J. D. Wright (ed.), International Encyclopedia of the Social and Behavioral Sciences, 2nd edition, Elsevier, Oxford 2015, pp. 580-585.

http://doi.org/10.1016/b978-0-08-097086-8.75014-8

communities living close to it, increase the number of fatal traffic accidents, and lead to the destruction of valuable natural habitats; funding of research on human genetic material may raise questions about using their results for medical and military aims; policy on illegal migrants can protect the jobs of citizens in current country, but it can be implemented by rigorous methods that lead to violations of human rights and damage the country's positive image abroad.

Stakeholder analysis in public policy is useful for mapping the power and interests of different groups (stakeholders) and resulting in a diagram that helps to plan their participation in policy implementation. This includes then, for example, informing and empowering stakeholders (Hermans and Cunningham, 2013). Diagnosis of interests and actors may also serve as a basis or justification for a program of action that will achieve that interest. For example, the program of education development at the same time may aim to increase the intergenerational relations and to the protection of nature after analyzing the expectations and opportunities for the involvement of older and younger people. Democratic procedures in the political system allow the articulation of interests. To gain political supporters' interests can be expressed in terms of protecting the interests of vulnerable groups. For example, the interests of our company are the interest of the country and the interests of many small shareholders, who work hard and save money; assistance to the poor is not to summarily grant money (shortterm and material interest), but on arousing and sustaining motivation to work (long-term and intangible interest). Public policy, therefore, requires ethical actions in the interests of the powerful and the weak, dispersed, and concentrated interests, public and particularistic interests.

\section{Values of Public Policy}

Values are what the individual, group, or organization considers as desirable, worth achievement, and action. In public policies primarily evaluated are social relations, the state of meeting the needs, institutions, and relationships between man and nature. The values of social relations include, for example, justice, freedom, solidarity, equality, and cooperation. The values associated with meeting the needs are, for example, social security, welfare, health, dignity, and self-realization. The values appearing in the evaluation of institutions include selfgovernance, agency, partnership, the common good, and efficiency. The relationship between man and nature determines among other values such as work and ecological balance. Indicators of choices are individual and group behaviors including, verbal (e.g., demands, evaluation) and 
A. Klimczuk, Public Policy: Ethics, [in:] J. D. Wright (ed.), International Encyclopedia of the Social and Behavioral Sciences, 2nd edition, Elsevier, Oxford 2015, pp. 580-585.

http://doi.org/10.1016/b978-0-08-097086-8.75014-8

nonverbal (e.g., efforts to gain access to desired goods, emotional states, such as satisfaction or dissatisfaction).

For public policy, crucial are relationships between the values of individuals and groups (Supińska, 2008a). These values can be fully compatible with each other (internalization of the group characteristics by the individuals). They can also be partially compliant when an individual accepts some part of the group values and recognizing them as a tool for achieving individual values. For example, some individuals accept freedom in social life since this can guarantee their own freedom. The third type of relationship is the inconsistency of group and individual values. This occurs, for example, when an individual matured in a different sociocultural context and not adapted to the new environment or when is rebelling against the group values. Moreover, public policy is examined whether the values adopted by the individuals are in accordance with the values advocated by various entities that are creating and implementing public policy - thus analyzed whether the values underlying the selected public programs are known for members of the society and whether they agree with the values of individuals and groups. Values in public policy are used for programming, organizing objectives, motivate to action, and justification of adopted legal norms. Knowledge of the social values gives the possibility to anticipate the arrival of new needs, increasing or decreasing of already occurring needs, or the efforts to meet the needs in a new way, by other means.

Valuing by public policy actors involves the use of assessment criteria related to the broader social, economic, cultural, political, and environmental context. For example, those are criteria on obligatory features (responding to the questions: what is consistent with the values? what corresponds to the norms and standards? what is good for society and for the development of the human person?) or instrumental features (whether achievement of group values will lead to the individual values? whether the implementation of the individual values is not detrimental to the common good?).

There are many sources of values in public policy. These include, among others, ideologies, social and economic doctrines, customs, and attitudes of significant moral and scientific authorities. In modern societies, particular importance to ethical debates in public policy is gained by public opinion and mass media (radio, television, Internet), which need a guarantee of speech and freedom of the press (Capurro, 2005). Choices of values in public policy and therefore choices of aims, principles, and their implementation programs take place under conditions of conflict of interest and building compromises. Public policies are not, therefore, implementing rather uniform and consistent value systems. 
A. Klimczuk, Public Policy: Ethics, [in:] J. D. Wright (ed.), International Encyclopedia of the Social and Behavioral Sciences, 2nd edition, Elsevier, Oxford 2015, pp. 580-585.

http://doi.org/10.1016/b978-0-08-097086-8.75014-8

Values also define the objectives and principles of public policy. Public policy objectives are determined by groups and organizations during policy formulation. These objectives may be general, such as comprehensive development, economic stability and competitiveness, social cohesion, high quality of life, access to nuclear power, adaptation to climate change, and ensuring help for refugees. Under such general goals are specific objectives such as within social cohesion: improving the position of vulnerable economically and socially groups, inequality and poverty alleviation, minimizing the social risk. Fundamentally ethical questions may concern whether these and other goals are actually important and, if so, how and why exactly they should be achieved (Supińska, 2008a).

\section{Principles of Public Policy}

From values are derived the principles of public policy, which can be understood as general guidelines and standards of activities, which should be guided by public policy actors in achieving their goals (Supińska, 2008a). These rules are different depending on the value systems defined in various social and economic doctrines as well as depending on the values adopted and implemented as significant (not always consciously) by public policy actors (which is described as policy style). The principles are an expression of values and directives designed to protect them.

Certain public policy principles are the same as values. For example, solidarity as a value describes the desirable attributes of social relations and institutions, and at the same time is the principle used as part of the public policy instruments such as social security systems. For example, self-governance is both a desirable feature of the institutions and the principle of their organization in the form of territorial public administration.

Among the principles of public policy can be distinguished: comprehensiveness, selflimitation, the common good, providence, forethought, self-help, solidarity, subsidiarity, participation, sustainable development, self-governance, and multisectorality (Luks, 2005; Bryner, 2006; Supińska, 2008a). These principles can be described as follows:

- The principle of comprehensiveness means that public policy entities should consider all the interests and opportunities to achieve goals and analyze all internal and external factors that may affect their usage.

- The principle of self-limitation means that the government does not have to intervene in all possible areas and sectors of the economy and society but should choose areas for action.

- The principle of the common good (cohesion) is the realization of individual interests so as to 
A. Klimczuk, Public Policy: Ethics, [in:] J. D. Wright (ed.), International Encyclopedia of the Social and Behavioral Sciences, 2nd edition, Elsevier, Oxford 2015, pp. 580-585.

http://doi.org/10.1016/b978-0-08-097086-8.75014-8

minimize conflicts between them (e.g., environmental conflicts, conflicts between the individual and social interests).

- The principle of providence means that under conditions of limited resources is essential to reduce costs but also to limit intervention, which, when is used in excess, can inhibit the private and social initiative.

- The forethought principle means that the safety of the individual can not only be the result of benefits from the public but should also result from individual responsibility for its own future. Forethought is the ability to give up part of the ongoing benefits to meet future needs and the pursuit of such activities, which minimizes the risk of threats (e.g., saving, healthy lifestyle, organization of insurance).

- The principle of self-help refers to the existence and development of mutual aid of people struggling with similar problems in life as well as support by stronger people for the weak. This assistance usually takes place within small, informal groups.

- The principle of solidarity is most often understood as a transfer of social risk consequences from individuals to society as well as the superiority of the common interests of society members over the interests of individuals, groups, and social classes.

- The principle of subsidiarity means the adoption of a specific order in which the various institutions undertake interventions such as providing support to the poor. This principle is based on the support in the first instance derived from closest entities (e.g., family, local community), and later help from the state institutions.

- The principle of participation describes an organization of social life, which allows individuals to fully realize their social roles and allows groups to have an equal position in society. This rule specifies the possibility of being a member of different social groups and communities and participate in their actions.

- The principle of sustainable development refers to the integration of political, economic, and social action on preserving the natural balance to ensure the possibility of satisfying the basic needs of both the present and future generations.

- The principle of self-governance is the implementation of such values as freedom and human agency. It is achieved through the organization of social life, which guarantees individuals and groups active participation in existing institutions and creating new institutions (informal entities and non-governmental organizations) to better meet the needs and pursue interests.

- The principle of multisectorality refers to the simultaneous functioning of different entities of public policy. This includes public entities (public administration), commercial entities (private, 
A. Klimczuk, Public Policy: Ethics, [in:] J. D. Wright (ed.), International Encyclopedia of the Social and Behavioral Sciences, 2nd edition, Elsevier, Oxford 2015, pp. 580-585.

http://doi.org/10.1016/b978-0-08-097086-8.75014-8

market), and non-governmental organizations (civil society, voluntary) that provide resources and services aimed at meeting the needs of society.

These principles do not cover all which are present in public policymaking and implementation. Different types of public policies, such as economic and social policies, are characterized by different rules. For example, social policies in liberal regimes of the welfare state are less focused on solidarity than on forethought and individual savings. At the same time, conservative regimes are highlighting subsidiarity and solidarity.

\section{Policy Style}

Styles of intervention are derived from public policy values. Policy style concept refers to the assumption that human behavior is important to factor in ethical choices and decisions of the policy actors, which influence on selecting and using more or less persuasive instruments to achieve policy objectives (Supińska, 2008b). Behaviors are, to a large extent, rational decisions of people based on the use of their freedom and to the pursuit of their life aspirations. However, the behavior of individual groups, for example, employees, students, parents, consumers, criminals, sick, teachers, police officers, and doctors, may differ from the socially expected norms. For example, teachers may focus on work with good students and not promote equality of opportunity for all; consumers can choose cheaper but less healthy food, police officers may be willing to accept bribes. Public policy interventions primarily aim to prevent further dissemination of the behaviors with negative social consequences as well as intervene to maintain and strengthen the already existing positive behaviors and seek ways to mobilize people to achieve objectives recognized publicly as the correct.

Policy style (style of policy implementation) refers to a set of public policy tools that are adapted to the characteristics of program recipients, which are the causes of undesired behaviors. The choice of intervention style should be preceded by a research and public debate, which will allow understanding the reasons for undesirable behaviors, overcoming stereotypes, recognize the social, economic, administrative, political, and environmental conditions of that behaviors as well, as choosing relevant objectives and principles for implementation of public policy.

Four basic policy styles may be described (Supińska, 2008b). These are liberal style, caring style, stimulating style, and rigorous style. Liberal style proves to be effective if the only problem with the policy recipients, who have appropriate aspirations and competency, is that they cannot realize their ambitions due to barriers that appeared in their life (such as low 
A. Klimczuk, Public Policy: Ethics, [in:] J. D. Wright (ed.), International Encyclopedia of the Social and Behavioral Sciences, 2nd edition, Elsevier, Oxford 2015, pp. 580-585.

http://doi.org/10.1016/b978-0-08-097086-8.75014-8

education, living in periphery region, lack of institutional capacity). Activities in this style give freedom to individuals and groups, expressing confidence in their competence. Caring style can be implemented when the main reason for the lack of desired behavior is the lack of skills and abilities among policy recipients. Recipients of programs based on this style are treated as persons that need permanent or transitional support until they achieve the desired behavior, skills, and competencies (e.g., help for people with disabilities). Stimulating style assumes that individuals, groups, and organizations can and may keep from negative behaviors or take the socially desired behaviors, but they do not want to (e.g., people choosing to drive their own car than public transport). This style assumes that the desired behaviors can be achieved by offering people some valuable benefits in return. For example, unwillingness to change the organization of business in accordance with the principles of safety and low energy usage can be reduced by proposing a public financial contribution to these investments; the reluctance to change the location of plants can be reduced by lowering taxes. Rigorous style refers to using sets of policy tools that may force the desired behavior. It is assumed here that recipients of the program (e.g., alcohol abusers or criminals) are able and may but do not want to abstain from condemned behaviors so that the desired behaviors can be activated upon them only under the pressure of fear from the onerous sanctions (e.g., they do not want to live honestly, but even more do not want to go to jail or pay the penalty).

Policy styles are also varied in different countries due to the various relationships between government and the public (consensus or imposition) as well as due to the dominant approach to problem-solving (anticipatory or reactive) (Richardson et al., 1982). During the formulation of any public programs is reasonable to determine the style which will be fundamental in pursuing specific objectives. It should also be noted that, in practice, public policies are combinations of various styles. The different stages of public policy may cover different possible styles. For example, on the agenda-setting stage, there may be used styles of outside initiation, inside initiation, consolidation, or mobilization (Howlett and Ramesh, 2003). While on the stage of policy implementation may be chosen institutionalized voluntarism, directed subsidization, representative legalism, or directed provision.

There are also different sequences of using policy styles. For example, first may be assumed the citizens' freedom, then the punishment of those who abuse this freedom then may take place reducing undesirable behaviors of the punished or encouraging to change aspirations. Each style allows not only to achieve short-term objectives of the program but also to contribute to the long-term transformation of personality and attitudes of citizens. This effect is particularly 
A. Klimczuk, Public Policy: Ethics, [in:] J. D. Wright (ed.), International Encyclopedia of the Social and Behavioral Sciences, 2nd edition, Elsevier, Oxford 2015, pp. 580-585.

http://doi.org/10.1016/b978-0-08-097086-8.75014-8

evident in the societies in which there has been a long tradition of using rigorous and caring styles by the state that also includes interventions into private life (e.g., it affected on low rates of social trust and citizen activities in post-socialist countries like Poland and Hungary).

\section{Ethics in the Policy Cycle}

Ethical decision making occurs at all stages of the policy cycle (Howlett and Ramesh, 2003; Donahue, 2008). Each stage includes different disputes over values and ethical dilemmas:

1. Agenda setting is a process by which problems come to the attention of governments. This stage includes problem recognition by public, private, and non-governmental organizations. Important issues are selected by governments into agenda as those that can and should be resolved. Ethical decisions are made during selecting issues because alternative values of policymakers may lead to different choices and objectives. Ethical judgments are also made during considering resources that may be used, and stakeholders should be satisfied.

2. Policy formulation refers to how policy options are formulated within the government. It starts from policy analysis by which possible solutions to problems are identified and proposed. The crucial part is the cost and benefits analysis of material and nonmaterial resources. Ethical judgments are related hereto choosing analysis methods, allocating resources, making assumptions on findings, and interpreting

3. Decision making refers to the process by which governments adopt a particular course of action or nonaction. At this stage, choices between alternative solutions are made by positive or negative decisions or nondecisions. This process allows the preparation of the program as well as clarify the objectives, activities, policy style, and balancing between conflicting objectives. The policy is discussed to be acceptable, legitimated by avoiding bad and doing good. Then adoption of the policy is done by law, public programs and strategies, executive orders, rules, and regulations.

4. Policy implementation refers to how governments put policies into effect. An implementation may be organized according to the program or maybe general and freely structured for policy improvements and flexible actions. Implementation usually includes a series of activities done by a variety of policy actors and stakeholders. Here public administrators and servants are confronted with ethical dilemmas about responding to authorities and stakeholders, action according to the professional codes. For example, dilemmas may occur when policy goals are too general, when stakeholders are trying to halt or alter implementation, and when different authorities have conflicting expectations. 
A. Klimczuk, Public Policy: Ethics, [in:] J. D. Wright (ed.), International Encyclopedia of the Social and Behavioral Sciences, 2nd edition, Elsevier, Oxford 2015, pp. 580-585.

http://doi.org/10.1016/b978-0-08-097086-8.75014-8

5. Evaluation refers to the processes by which the results of policies are monitored by the state, private, and societal actors, the outcome of which may be a reconceptualization of policy problems and solutions. Implemented solutions are evaluated in terms of whether or not they brought the expected results and whether there are any unexpected effects. Policies may not achieve all goals due to ambiguous goals, choosing inadequate action, not taking into account specific conditions, incorrect selection of indicators. Evaluation helps to find reasons why the programs did not respond to the needs of their recipients and explain processes of intervention and outcomes. Ethical dilemmas refer here to choosing appropriate measures, objectively collecting data, and interpreting findings. Ethical questions are also posed in responding to stakeholders and deciding on a continuing policy, changing it, or discontinuing.

Described examples show only some of the possible problems, dilemmas, and ethical decisions which occur in the practice of public policy and that may be the subject of further analysis.

\section{Conclusion}

The public policy includes directly or indirectly making ethical judgments. Ethical decisions are taken mainly by policymakers by selection and reconciliation of interests represented by individuals, groups, and organizations. Public policy is based on balancing individual and social values. From those values arise its objectives, principles, and styles of policy implementation and intervention. All choices and decisions in public policy at each stage of the policy cycle are ethical judgments because they presuppose that some things are more important than others, that some actions will have positive and others will have a negative impact on society. Policy debates can be more productive by using ethical approaches. Ethics enables a systematic analysis of the rules and standards as well as the selection of rational public decisions.

See also: Attitudes, Political and Civic Culture; Civil Service; Corruption: Political and Public Aspects; Decision Making, Psychology of; Economics and Ethics; Leadership; Planning Ethics; Quality of Government; Responsibility: Philosophical Aspects.

\section{References}

Bellinger, W.K., 2007. The Economic Analysis of Public Policy. Routledge, London, New York.

Boston, J., Bradstock, A., Eng, D., 2010. Ethics and public policy. In: Boston, J., Bradstock, 
A. Klimczuk, Public Policy: Ethics, [in:] J. D. Wright (ed.), International Encyclopedia of the Social and Behavioral Sciences, 2nd edition, Elsevier, Oxford 2015, pp. 580-585.

http://doi.org/10.1016/b978-0-08-097086-8.75014-8

A., Eng, D.L. (Eds.), Public Policy: Why Ethics Matters. ANU E Press, Canberra, pp. 117.

Bryner, G., 2006. Ethics and public policy. In: Peters, B.G., Pierre, J. (Eds.), Handbook of

Public Policy. Sage Publications, London, Thousand Oaks, CA, pp. 433-442.

Capurro, R., 2005. Ethics and public policy within a digital environment. In: General Report

on the Activities of the European Group on Ethics in Science and New Technologies to the

European Commission, 2000-2005. Office for Official Publications of the European

Communities, Luxembourg, pp. 19-25.

Dębowski, J., Jedynak, S., 1999. Mały stownik etyczny (Glossary of Ethics). Branta,

Bydgoszcz, Poland.

Donahue, A.K., 2008. Ethics and public policy. In: Berman, E.M., Rabin, J. (Eds.),

Encyclopedia of Public Administration and Public Policy. Taylor \& Francis, New York,

London, pp. 696-700.

Hermans, L., Cunningham, S., 2013. Actor models for policy analysis. In: Thissen, Wil A.H.,

Walker, W.E. (Eds.), Public Policy Analysis. Springer, New York, pp.185-213.

Howlett, M., Ramesh, M., 2003. Studying Public Policy: Policy Cycles and Policy

Subsystems. Oxford University Press, Toronto, New York.

Luks, K., 2005. Polityka gospodarcza: Wybrane zagadnienia (Economic Policy: Selected

Issues). Zakład Wydawnictw Naukowych Instytutu Morskiego, Gdańsk, Poland.

Peterson, S.A.,2008.Values and policy analysis. In: Berman, E.M., Rabin, J. (Eds.),

Encyclopedia of Public Administration and Public Policy. Taylor \& Francis, New York,

London, pp. 2026-2027.

Richardson, J., Gustafsson, G., Jordan, G., 1982. The concept of policy style. In: Richardson,

J.J. (Ed.), Policy Styles in Western Europe. Allen \& Unwin, London, pp. 1-16.

Shue, H., 2006. Ethical dimensions of public policy. In: Moran, M., Rein, M., Goodin,

R.E.(Eds.),The Oxford Handbook of Public Policy. Oxford University Press, Oxford, New York, pp. 709-728.

Sullivan, E., Segers, M., 2007. Ethical issues and public policy. In: Fischer, F., Miller, G.,

Sidney, M.S. (Eds.), Handbook of Public Policy Analysis: Theory, Politics, and Methods.

CRC/Taylor \& Francis, Boca Raton, pp. 309-328.

Supińska, J., 2008a. Wartości i zasady polityki społecznej (Values and principles of social

policy). In: Firlit-Fesnak, G., Szylko-Skoczny, M. (Eds.), Polityka społeczna (Social

Policy). PWN, Warszawa, Poland, pp. 71-80. 
A. Klimczuk, Public Policy: Ethics, [in:] J. D. Wright (ed.), International Encyclopedia of the Social and Behavioral Sciences, 2nd edition, Elsevier, Oxford 2015, pp. 580-585.

http://doi.org/10.1016/b978-0-08-097086-8.75014-8

Supińska, J., 2008b. Style i instrumenty polityki społecznej (Style and instruments of social policy). In: Firlit-Fesnak, G., Szylko-Skoczny, M. (Eds.), Polityka społeczna (Social Policy). PWN, Warszawa, Poland, pp. 81-91.

Weimer, D.L., Vining, A.R., 1999. Policy Analysis: Concepts and Practice. Prentice Hall, Upper Saddle River, NJ.

Wolff, J., 2011. Ethics and Public Policy: A Philosophical Inquiry. Routledge, Milton Park Abingdon Oxon, New York.

Zybała, A., 2012. Polityki publiczne (Public Policy). Krajowa Szkoła Administracji Publicznej, Warszawa, Poland. 